\title{
Annual production of microalgae in wastewater using pilot-scale thin-layer cascade photobioreactors
}

Ainoa Morillas-España ${ }^{1 *}$, Tomás Lafarga ${ }^{1}$, Francisco Gabriel Acién-Fernández ${ }^{1}$, Cintia Gómez-Serrano¹, \& Cynthia Victoria González-López ${ }^{1}$

${ }^{1}$ Department of Chemical Engineering, University of Almería, 04120, Almería, Spain.

Corresponding author: $\underline{\text { ame778@ual.es }}$ 


\section{Abstract}

Microalgae based wastewater treatment has been suggested as an alternative to polluting and energy-consuming conventional processes. The main advantage of this strategy is the dual role of microalgae: they recover nutrients from waste and simultaneously produce biomass with varied industrial applications. In the current study, biomass of Scenedesmus sp. was produced using primary wastewater in two pilot-scale thin-layer cascade photobioreactors (63 and $126 \mathrm{~m}^{2}$ ). The wastewater used for microalgal growth was not subjected to any conventional treatment process, besides removal of solids, and contained a variable $\mathrm{N}_{-} \mathrm{NH}_{4}{ }^{+}$ content of $83.0-210.6 \mathrm{mg} \cdot \mathrm{L}^{-1}$. Biomass productivity values were comparable to those obtained when operating using freshwater and commercial chemicals as nutrient sources. When operating at a dilution rate of $0.3 \mathrm{day}^{-1}$, the average annual productivity was $24.8 \mathrm{~g} \cdot \mathrm{m}^{-2} \cdot \mathrm{day}^{-1}$ $\left(82.0 \mathrm{t} \cdot \mathrm{ha}^{-2} \cdot \mathrm{year}^{1}\right)$ with a maximum of $32.8 \mathrm{~g} \cdot \mathrm{m}^{-2} \cdot \mathrm{day}^{-1}$ in summer. Inorganic nitrogen and phosphorus removal rates varied between $695.4-2383.4$ and $70.4-111.8 \mathrm{mg} \cdot \mathrm{m}^{-2} \cdot \mathrm{day}^{-1}$ respectively. Production of Scenedesmus sp. using wastewater would allow not only to process large volumes of water that could be reused for agricultural irrigation or safely disposed into water streams, but also reduce production costs by $0.44 € \cdot \mathrm{kg}^{-1}$, based on a preliminary economic analysis. Overall, results demonstrate that thin-layer cascade reactors can be used to effectively remove nutrients from wastewater while simultaneously produce valuable biomass with potential applications in agriculture or animal feed production.

Keywords: Bioremediation, microalgae, water reuse, biomass productivity, circular economy. 


\section{Introduction}

Providing more sustainable practices for not only natural resources but also waste management is one of the key elements in the transformation towards a circular economy. Water and wastewater management is one of the biggest challenges for humans: limited access to clean water limits both production capacity and profits (Smol et al., 2020) and was ranked as the global risk of the most devastating impact by the World Economic Forum (Sgroi et al., 2018). Conventional wastewater treatment plants contribute to climate change through the emission of greenhouse gases and require high levels of energy and resource consumption (Muga and Mihelcic, 2008). In the EU, water and wastewater treatment accounts for approximately $7-8 \%$ of the overall energy consumption (Sgroi et al., 2018). Processes based on microalgae-bacteria have emerged as one of the most promising strategies to minimise the environmental impact of wastewater treatment.

The exploitation of photosynthesis to process wastewater is particularly interesting: microalgae use sunlight (an inexhaustive source of energy) and carbon dioxide (a chemical compound we want to get rid of) to transform inorganic nutrients (such as ammonia, nitrates, and phosphates) into oxygen and valuable biomass (Lafarga, 2020). The oxygen produced by microalgae is used by heterotrophic bacteria, present in wastewater, to oxidise organic matter into inorganic nutrients and produce carbon dioxide, both needed for microalgal growth (Sánchez-Zurano et al., 2021). One of the main advantages of this strategy is that the biomass produced during wastewater treatment could be further used to formulate products for agriculture, such as biofertilisers or biostimulants, or animal feeds and other high-value applications.

Microalgae are produced in controlled industrial facilities using photobioreactors that can be divided into two main groups: open and closed systems. The latter are highly productive and easier to control but, because of their higher cost, are used for high-end applications where monocultures are required (food, cosmetics, pharmaceutics, chemicals, etc.). Open systems are cheaper to build and operate. One of their main disadvantages is that as they are open to 
the environment, the risk of contamination with other microalgal strains and microorganisms is higher. However, this is not a problem in wastewater treatment processes where the interaction of microalgae with bacteria is desired. Most common open systems are open ponds or raceways. The culture depth or raceways generally ranges between 0.2 and $0.3 \mathrm{~m}$, which allows to process large volumes of water per surface area but their (current) design does not allow to optimise light utilisation (Barceló-Villalobos et al., 2019a). Light availability is the most important factor influencing microalgal growth. Thin-layer cascade systems are operated with a shallow water column $(0.5-5.0 \mathrm{~cm})$ which allows to maximise light availability and, therefore, biomass concentration and productivity (Doucha and Lívanský, 2009). For example, Scenedesmus sp. productivity using a pilot-scale thin-layer cascade reactor reached 30-35 $\mathrm{g} \cdot \mathrm{m}^{-2} \cdot$ day $^{-1}$ while lower values of $20-25 \mathrm{~g} \cdot \mathrm{m}^{-2} \cdot$ day $^{-1}$ were obtained for raceways located inside the same greenhouse during the same season (Morillas-España et al., 2020).

Currently, microalgae-based wastewater processes are being demonstrated and validated at large-scale in several locations such as Christchurch (New Zealand) and Cadiz (Spain) (Sánchez Zurano et al., 2020). However, most of the data available in the literature were obtained from indoor experiments, and the up-scaling of microalgae-based wastewater treatment processes is rare. Treatment of anaerobically digested piggery effluent was conducted outdoors using pilot-scale thin-layer reactors $\left(0.5 \mathrm{~cm}\right.$ depth, $\left.0.35 \mathrm{~m}^{3}\right)$ and raceways (15 cm depth, $\left.1.5 \mathrm{~m}^{3}\right)$. Thin-layer reactors allowed a 1.4 times higher removal rate of $\mathrm{N}-\mathrm{NH} 4+$, demonstrating the huge potential of thin-layer reactors to process waste streams and wastewaters (Raeisossadati et al., 2019). Although thin-layer cascade reactors are highly productive and one of the top trends in microalgal biotechnology, information about their performance is limited to laboratory- or pilot-scale (up to $50 \mathrm{~m}^{2}$ ) reactors. For these reasons, the goals of the current study were to assess the potential of Scenedesmus sp. and thin-layer cascade photobioreactors to recover nutrients from wastewater and assess the effect of environmental conditions on biomass productivity and on the performance of the system. Two different pilot-scale thin-layer cascade designs located inside a greenhouse were assessed 
and operated for 12 months using wastewater, with very high nitrogen and phosphorus concentration, as the sole nutrient source.

\section{Materials and methods}

\subsection{Selected microorganism}

The strain selected was Scenedesmus sp. (CCAP 276/24), available at the culture collection of the University of Almería, Spain. This strain was selected because it is fast-growing and highly-productive and it is also particularly adapted to the environmental conditions in the south of Spain (Morales-Amaral et al., 2015a, 2015b; Morillas-España et al., 2020). The initial inocula were prepared using $5 \mathrm{~L}$ photobioreactors at laboratory scale and were further upscaled using $80 \mathrm{~L} \mathrm{pH}$-controlled bubble columns as described previously (Morillas-España et al., 2020). The bubble columns were located inside a greenhouse together with the thin-layer cascade photobioreactors. The culture medium of the columns was composed of $0.90 \mathrm{~g} \cdot \mathrm{L}^{-1}$ $\mathrm{NaNO}_{3}, 0.18 \mathrm{~g} \cdot \mathrm{L}^{-1} \mathrm{MgSO}_{4}, 0.14 \mathrm{~g} \cdot \mathrm{L}^{-1} \mathrm{~K}_{2} \mathrm{HPO}$, and $0.03 \mathrm{~g} \cdot \mathrm{L}^{-1}$ of Karentol ${ }^{\circledR}$ (Kenogard, Spain), which is a commercial solid mixture of micronutrients.

\subsection{Photobioreactor and operation conditions}

Two different thin-layer photobioreactors were evaluated: a single-channel photobioreactor with a total volume of $2.4 \mathrm{~m}^{3}$ and a land surface of $63 \mathrm{~m}^{2}$, named as TL1, and a double-channel photobioreactor with a total volume of $3.6 \mathrm{~m}^{3}$ and a land surface of $126 \mathrm{~m}^{2}$, named as TL2 (Figure 1). The reactors channels were built in glass fibre and are elevated $1.5 \mathrm{~m}$ from the ground. The channels had a slope of $1 \%$ and allowed an average culture velocity of $0.2 \mathrm{~m} \cdot \mathrm{s}^{-}$ 1. The surface-to-volume ratios of TL1 and TL2 were 26.3 and $35.0 \mathrm{~m}^{2} \cdot \mathrm{m}^{-3}$ respectively. Both were operated at a culture depth was $0.02 \mathrm{~m}$ and were provided with a degasser (a $250 \mathrm{~L}$ bubble column with continuous injection of air at $75 \mathrm{~L} \cdot \mathrm{min}^{-1}$ ) and a collector to increase the volume of the system. The volume of culture in the collector and in the bubble column summed up $1.0 \mathrm{~m}^{3}$. The $\mathrm{pH}$, temperature, and dissolved oxygen concentration of the culture were 
measured using 5083T and 5120 probes (Crison Instruments, Spain) connected to an MM44 control-transmitter unit (Crison Instruments, Spain) and Labview data acquisition software (National Instruments, US) providing complete monitoring of the facilities. The sensors were located at the end of the channel. The $\mathrm{pH}$ was controlled by on-demand injection of $\mathrm{CO}_{2}$ and evaporation was daily compensated by addition of freshwater.

Both reactors were operated on semi-continuous mode at a dilution rate of 0.3 day $^{-1}$, which means that every day $30 \%$ of the cultures' volume $(720$ and $1080 \mathrm{~L}$ for TL1 and TL2, respectively) was harvested and replaced with fresh culture media, in this case primary wastewater. The reactors were operated $24 \mathrm{~h}$ per day and the semi-continuous mode was maintained until the total volume of the reactors was replaced at least twice (7-8 days). The production process was repeated at least three times per season, being each production run the experimental unit. Three technical replicates were performed per natural replicate.

\subsection{Wastewater composition}

The wastewater used was domestic wastewater collected from the sewerage of the University of Almería (Almeria, Spain). Domestic wastewater includes blackwater (wastewater from toilets) and greywater (water used for washing, bathing and kitchen. The wastewater consisted mainly of blackwater: 20,000 people with only a limited number of kitchens, showers, and washing machines. The wastewater used was not subjected to any conventional depuration treatment besides removal of solids. For these reasons, the nutrient and bacterial load of the inlets was highly variable and, depending on the season, high when compared to conventional urban wastewater. The $\mathrm{N}-\mathrm{NH}_{4}{ }^{+}, \mathrm{N}-\mathrm{NO}_{3}{ }^{-}$, and $\mathrm{P}-\mathrm{PO}_{4}{ }^{3-}$ content of the wastewaters used varied within 93.6-210.6, 1.9-3.7, and 11.3-13.0 $\mathrm{mg} \cdot \mathrm{L}^{-1}$, respectively.

\subsection{Analytical determinations}

Biomass concentration $\left(C_{b}\right)$ was calculated by dry weight, filtering $100 \mathrm{~mL}$ of culture through $1 \mu \mathrm{m}$ filters and drying at $80^{\circ} \mathrm{C}$ in an oven for $24 \mathrm{~h}$. Biomass included not only the inoculated Scenedesmus sp. microalga but also other microalgae and bacteria present in the microalgae- 
bacteria consortia. Areal biomass productivity $\left(P_{b}\right)$ was calculated as the product of biomass concentration and the dilution rate $\left(0.3\right.$ day $\left.^{-1}\right)$ using the equation:

$$
P_{b}\left(g \cdot m^{-2} \cdot d a y^{-1}\right)=\frac{C_{b} \cdot D \cdot V}{A}
$$

where $D$ is the dilution rate imposed $\left(0.3\right.$ day $\left.^{-1}\right), V$ is the volume of the culture expressed in $\mathrm{L}$, and $A$ is the surface of the reactor expressed in $\mathrm{m}^{2}$.

The variable chlorophyll fluorescence ratio $\left(F_{v} / F_{m}\right)$ was determined using an AquaPen AP 100 fluorometer (Photon System Instruments, Czech Republic). Microalgal cells were darkadapted for 5 min prior to the determination of $F_{v} / F_{m}$ values (Morales-Amaral et al., 2015a). The absorbance $(A b s)$ of the culture at $400-700 \mathrm{~nm}$ was daily measured using a GENESYS 10S UV-Vis spectrophotometer (Thermo Fisher Scientific, Spain). The extinction coefficient $\left(k_{a}\right)$ and the average irradiance inside the culture $\left(I_{a v}\right)$ were calculated as described previously (Morillas-España et al., 2020) using the equations:

$$
k_{a}=\frac{A b s}{C_{b} \cdot p}
$$

and

$$
I_{a v}\left(\mu \mathrm{mol} \text { photon } \cdot m^{-2} \cdot s^{-1}\right)=\frac{I_{0}}{k_{a} \cdot C_{b} \cdot p} \cdot\left(1-e^{-k_{a} \cdot C_{b} \cdot p}\right)
$$

where $I_{0}$ is the irradiance at the surface of the culture and $p$ the light path inside the reactor.

The concentration of ammonium, nitrates, and phosphates at the inlet and outlet of TL1 and TL2 was measured using standard official methods approved by the Spanish Ministry of Agriculture - described previously (Sánchez Zurano et al., 2020). Briefly, phosphorus and nitrates were measured spectrophotometrically through the phospho-vanado-molybdate complex and by measuring the absorbance at 220-275 nm using Genesys 10S UV-Vis spectrophotometer (Thermo Fisher Scientific, Spain). The concentration of ammonium was determined using the Nessler reactive method. Analytical determinations were conducted 
daily. Three technical replicates for all the studied parameters were conducted per natural replicate.

\subsection{Economic analysis}

An economic analysis was conducted following a previously reported methodology (Acién et al., 2012). Briefly, the cost of equipment used was obtained from the suppliers and was used to calculate the total fixed capital by multiplying the equipment's cost and their corresponding Lang factors. Total production cost was calculated as the sum of the depreciation plus the direct production costs. Depreciation includes the amortisation of the fixed capital, property taxes, insurances, and purchase taxes. Direct production costs included raw materials, utilities, labour, and other including supervision, maintenance, tax, contingency, etc. For the analysis, the present study assumed a theoretical $10,000 \mathrm{~m}^{2}$ reactor and set: (i) the cost of commercial fertilisers and $\mathrm{CO}_{2}$ as 0.4 and $0.1 € \cdot \mathrm{kg}^{-1}$ (Morales-Amaral et al., 2015b); the cost of thin-layer cascade photobioreactors as $200 € \cdot \mathrm{m}^{-3}$ (Morales-Amaral et al., 2015b); (iii) the cost of freshwater as $0.0002 € \cdot \mathrm{m}^{-3}$; (iv) the productivity of the thin-layer cascade reactors when operated using freshwater and commercial fertilisers as $24.8 \mathrm{~g} \cdot \mathrm{m}^{-2} \cdot$ day $^{-1}$ (Morillas-España et al., 2020); and (v) 330 days of production per year, leaving 35 annual days for maintenance and cleaning operations.

\subsection{Statistical analysis}

Normality and homoscedasticity of the variables within each group were checked. Data were analysed using analysis of variance with JMP 13 (SAS Institute Inc., USA). A Tukey pairwise comparison of the means was carried out to identify where sample differences occurred with a criterion of $p<0.05$. A bivariate Pearson's' correlation analysis was conducted to identify relationships between different variables.

\section{Results}




\subsection{Biomass productivity}

Temperature and solar radiation values were online monitored during the 12 months of the study and results are summarised in Figure 1. As expected, higher maximum temperatures and solar radiation values were observed in summer while no major differences were detected between spring and autumn $(p=0.002)$. Environmental conditions had a striking effect on the conditions of the culture and therefore on biomass production and nutrient removal capacity. Indeed, culture temperature and solar radiation were positively correlated $\left(R^{2}=0.849\right)$. During summer, the maximum temperature reached in the culture ranged between 35 and $40{ }^{\circ} \mathrm{C}$ (Figure 2). These values were maintained for a short period of time but still, could be lethal to certain microalgal strains and other microorganisms. Higher solar radiation on the surface led a higher average radiation inside the culture, especially higher in summer $(p=0.01)$. No differences were observed between $I_{a v}$ values in TL1 and TL2 as both reactors were operated with an identical culture depth and reached similar biomass concentrations. In the current study, average $I_{a v}$ values wer

e $52.3 \pm 4.1,94.3 \pm 6.9,108.7 \pm 9.2$, and $76.8 \pm 8.4 \mu \mathrm{mol}$ photons $\cdot \mathrm{m}^{-2} \cdot \mathrm{s}^{-1}$. As mentioned before, light availability is the most important factor for the production of photosynthetic organisms. Indeed, $I_{a v}$ values were positively correlated with biomass productivity in both TL1 $\left(R^{2}=0.963 ; 0.05\right)$ and TL2 $\left(R^{2}=0.989 ; 0.05\right)$. In the current study, oxygen concentrations over $300 \%$ saturation were detected in both reactors, and were especially high in TL2 during the whole year (Figure 2). Figure 2 also shows the average maximum, mean, and minimum $\mathrm{pH}$ vales measured per season. Results demonstrate an accurate $\mathrm{pH}$ control of the system, which is important to, for example, avoid precipitation of phosphorus and maximise microalgal growth. Values were kept within the range 7.0-9.0 during the complete duration of the experiment.

Biomass productivity values reached $16.9-32.9 \mathrm{~g} \cdot \mathrm{m}^{-2} \cdot$ day $^{-1}$ in TL1 and 20.5-28.6 $\mathrm{g} \cdot \mathrm{m}^{-2} \cdot$ day $^{-1}$ in TL2 (Figure 3). No differences were observed between both reactors, suggesting an average annual productivity of $24.8 \mathrm{~g} \cdot \mathrm{m}^{-2} \cdot$ day $^{-1}\left(82.0 \mathrm{t} \cdot \mathrm{ha}^{-2} \cdot \mathrm{year}^{-1}\right)$ when operating at a dilution 
rate of 0.3 day $^{-1}$ under the environmental conditions described in Figure 1. In addition, the $\mathrm{F}_{\mathrm{v}} / \mathrm{F}_{\mathrm{m}}$ value measures the performance of the photochemical processes in the PSIl complex, indicating if the culture is subjected to a certain stress condition. In the current study, $F_{v} / F_{m}$ values ranged between 0.4 and 0.5 (Figure 3). No major differences were observed between $F_{v} / F_{m}$ values except for a lower value in summer for the culture produced in TL2.

\subsection{Nutrient removal}

The content of main inorganic nutrients $\left(\mathrm{N}^{-} \mathrm{NH}_{4}{ }^{+}, \mathrm{N}-\mathrm{NO}_{3}{ }^{-}\right.$, and $\left.\mathrm{P}-\mathrm{PO}_{4}{ }^{3-}\right)$ of the wastewater used was determined and results are shown in Figure 4. The content of $\mathrm{N}-\mathrm{NO}_{3}{ }^{-}$and $\mathrm{P}-\mathrm{PO}_{4}{ }^{3-}$ in the inlets varied between 1.9-3.6 and 11.3-13.0 mg. $\mathrm{L}^{-1}$ and were comparable to those reported previously for urban wastewater (Sánchez Zurano et al., 2020). The $\mathrm{N}-\mathrm{NH}_{4}{ }^{+}$content of the wastewaters used ranged within $93.6-210.6 \mathrm{mg} \cdot \mathrm{L}^{-1}$ depending on the season. Besides inorganic nutrients, the wastewater contained organic matter including, for example, urea or proteins which contributed to the total nitrogen and phosphorus input. The content of $\mathrm{N}_{-} \mathrm{NH}_{4}{ }^{+}$ in the outlets was significantly lower during the four seasons and (almost) all the $\mathrm{N}-\mathrm{NH}_{4}{ }^{+}$ present in the wastewater was either consumed by microalgae or used by nitrifying bacteria to produce $\mathrm{N}-\mathrm{NO}_{3}$. Moreover, a mass balance conducted to both reactors (assuming a nitrogen content of the organic matter of $10 \%$ ) demonstrated that a large percentage of $\mathrm{N}$ $\mathrm{NH}_{4}{ }^{+}$present in the media was "lost" by stripping (desorption). This was especially high for TL1 (25-55\% of total $\left.\mathrm{N}-\mathrm{NH}_{4}{ }^{+}\right)$. N-NH${ }_{4}^{+}$removal capacity values ranged between 1039.0$2280.3 \mathrm{mg} \cdot \mathrm{m}^{-2} \cdot \mathrm{day}^{-1}$, being higher in those seasons with higher photosynthetic activity. Higher $\mathrm{N}-\mathrm{NH}_{4}{ }^{+}$removal values were observed in TL1 when compared to TL2 except during winter. N$\mathrm{NH}_{4}{ }^{+}$removal and biomass productivity were positively correlated in both $\mathrm{TL} 1\left(R^{2}=0.688\right)$ and TL2 $\left(R^{2}=0.764\right)$. Despite the low $\mathrm{N}^{-\mathrm{NO}_{3}}{ }^{-}$concentration in the inlet it was still present in the outlets, in some cases even at a higher concentrations. Overall, the total nitrogen consumption ranged within 938.5-2383.4 $\mathrm{mg} \cdot \mathrm{m}^{-2} \cdot$ day $^{-1}$ in TL1 and from $695.4-1782.3 \mathrm{mg} \cdot \mathrm{m}^{-2} \cdot$ day $^{-1}$ in TL2. The content of $\mathrm{P}_{-} \mathrm{PO}_{4}{ }^{3-}$ in the outlets was lower than in the inlets for all four seasons and $\mathrm{P}$ $\mathrm{PO}_{4}{ }^{3-}$ removals varied between 95.5-111.8 $\mathrm{mg} \cdot \mathrm{m}^{-2} \cdot \mathrm{day}^{-1}$ in TL1 and between 86.3-89.2 $\mathrm{mg} \cdot \mathrm{m}^{-}$ 
2. day ${ }^{-1}$ in TL2. The $\mathrm{P}_{-} \mathrm{PO}_{4}{ }^{3-}$ was used for microalgal growth, as all the $\mathrm{P}_{-} \mathrm{PO}_{4}{ }^{3-}$ removed from the wastewater was either present in the outlets or in the biomass (assuming a phosphorus content of $1 \%$ ). Despite the lower content of $\mathrm{P}_{-} \mathrm{PO}_{4}{ }^{3-}$ in the outlet of $\mathrm{TL2}$, higher areal recoveries were measured in TL1 because of its lower surface-to-volume ratio.

\subsection{Theoretical large-scale productivity and economics}

Up-scaling these results to a theoretical $10,000 \mathrm{~m}^{2}$ reactor would allow to process $21,780 \mathrm{~m}^{3}$ and recover 5-6 t of nitrogen $\left(\mathrm{N}-\mathrm{NH}_{4}{ }^{+}\right.$and $\left.\mathrm{N}^{-N_{3}}{ }^{-}\right)$and approximately 0.4 t of $\mathrm{P}_{-}-\mathrm{PO}_{4}{ }^{3-}$. Using this theoretical $10,000 \mathrm{~m}^{2}$ thin-layer cascade reactor, it would be possible to produce $80-90$ t.year ${ }^{-1}$ of valuable microalgal biomass, although there is technological potential to improve this value even further. These values were calculated using the average of the seasonal productivities reported in the current study and assuming 330 days of operation per year.

A preliminary economic analysis was performed on this theoretical $10,000 \mathrm{~m}^{2}$ reactor based on a previously reported methodology (Acién et al., 2012). The cost of nutrients, freshwater and thin-layer cascade reactors was set as described in previous scientific publications. Briefly, the total cost of major equipment summed up 95,835.06€ in both scenarios (freshwater and wastewater) representing $30.6 \%$ of the total fix capital, which was $313,731.89 €$ - land was not considered. Construction costs (19.7\%) and piping (9.2\%) were the second and third most important items contributing to the total fix capital. The direct production costs were highly influenced by the use of wastewater instead of freshwater and commercial nutrients. In the case of the photobioreactors operated using wastewater, the raw materials annual cost was 12.523.50€ and was entirely dedicated to carbon dioxide. In turn, when producing the biomass using freshwater and commercial chemicals as the source of nutrients, the cost of the raw materials was $46,649.42 €(21 \%$ nutrients and $79 \%$ carbon dioxide). The cost of water was below $1 \%$ as we assumed water recirculation. Moreover, the carbon dioxide requirements were lower in the photobioreactors operating with wastewater as in this case, microalgae can use the carbon dioxide produced by bacteria and also the organic matter present in the 
wastewater can be assimilated by microalgae as carbon or nitrogen sources (Wang et al., 2016).

\section{Discussion}

When produced outdoors, microalgal growth depends mainly on environmental conditions, namely temperature and solar radiation. Besides environmental factors, the dilution rate used directly influence biomass productivity. In the current study, the reactors were operated at a dilution rate of 0.3 day $^{-1}$, which demonstrated to be the optimum independently of the season (Morillas-España et al., 2020). Figure 2 shows the temperature of the culture, which was equal in both reactor designs indicating that the different volume-to-surface ratio of the reactors did not influence this variable. The high temperatures achieved demonstrate the importance of selecting a robust (and productive) microalgal strain capable to grow under a wide range of environmental conditions (Barceló-Villalobos et al., 2019b). In this case, we selected a local strain which was isolated for the first time inside a greenhouse exposed to high temperatures and solar irradiance $\left(45^{\circ} \mathrm{C}\right.$ and $2,000 \mu \mathrm{mol}$ photons $\cdot \mathrm{m}^{-2} \cdot \mathrm{s}^{-1}$ respectively) (Sánchez et al., 2008) and is able to grow well at $\mathrm{pH}$ and salinity values within the ranges $7-10$ and $0-5 \mathrm{~g} \cdot \mathrm{L}^{-1}$ respectively (Sánchez et al., 2008).

The oxygen produced by microalgae during photosynthesis can have a negative effect on the systems performance and, for this reason, the removal of the oxygen from the culture is important. Indeed, oxygen concentrations in the range $350-400 \%$ led to inhibition of microalgal growth previously when using thin-layer cascade reactors (Morillas-España et al., 2020). The reason for high oxygen saturation levels in thin-layer cascade reactors is their high productivity, which almost doubles oxygen production when compared to raceways. In the present study, the maximum saturation values reached suggest an ineffective oxygen removal, which will be improved in further studies. The $\mathrm{pH}$ of the culture was well controlled throughout the year and, as highlighted before, the strain produced during the current study can grow well under pH values of 7.0-10.0 (Sánchez et al., 2008). Overall, environmental 
conditions highly influenced the cultures' temperature, average irradiance inside the culture, and dissolved oxygen concentration, which play a key role on the performance of the system.

In terms of biomass productivity, results were in line with previous reports that demonstrated that the productivity of thin-layer cascade reactors is higher than that of raceways (MorillasEspaña et al., 2020). However, maximum productivities reached herein were lower than those obtained previously using outdoor thin-layer cascade reactors. For example, the productivity of a $32 \mathrm{~m}^{2}$ thin-layer cascade reactor with a culture depth of $0.02 \mathrm{~m}$ located in the same region reached $47.3 \mathrm{~g} \cdot \mathrm{m}^{-2} \cdot$ day $^{-1}$ in a previous report (Sánchez Zurano et al., 2020). It is important to highlight that microalgae production using wastewater depends largely on the composition of the wastewater used. In the current study, after applying a mass balance to the system, it was observed that the microalgal growth was nitrogen-limited. Assuming a nitrogen content of the biomass of $8.0 \%$, the mass balance indicates that microalgae utilised organic matter as a source of nitrogen and phosphorus. Depending on the season, approximately 700-100 and $550-800 \mathrm{mg} \cdot \mathrm{m}^{-2} \cdot \mathrm{day}^{-1}$ of organic nitrogen were removed from the wastewater in TL1 and TL2 respectively. A more in depth characterisation of the inlets and outlets of the reactors would be interesting as organic compounds and contaminants are generally overlooked in the literature. Adding nutrients to the wastewater would probably lead to increased biomass productivities, as biomass productivity values of $42 \mathrm{~g} \cdot \mathrm{m}^{-2} \cdot \mathrm{day}^{-1}$ were reported for thin-layer cascade reactors operating with centrate as the nutrient source once the $\mathrm{N}-\mathrm{NH}_{4}{ }^{+}$concentration was optimised(Morales-Amaral et al., 2015b). However, this would contrast with the aim of wastewater treatment processes that is removing nutrients from wastewater. Another alternative that is currently being assessed by a number of research groups is the utilisation of membranes that allow to separate the hydraulic retention time from the cellular retention time thus allowing to process larger volumes of water per surface area. This strategy allows increasing the amount of nutrients that enter the reactor without need to supplement the wastewater with salts. Moreover, microalgal growth could have also been partially affected by 
the high dissolved oxygen concentrations within the range $300-400 \%$ saturation, that led to growth inhibition previously (Morillas-España et al., 2020).

Optimal $F_{v} / F_{m}$ values for microalgal strains are frequently near 0.7 (Santabarbara et al., 2019). The $F_{v} / F_{m}$ values obtained in the current study were lower than that and slightly lower than those reported for the same strain when produced using freshwater and commercial chemicals as the source of nutrients (Morillas-España et al., 2020). This indicates that the cells were subjected to some stress condition and therefore the capacity and activity of photosynthesis was negatively affected by wastewater (Wang et al., 2019). This was probably caused by the fact that the wastewater was not subjected to any previous depuration process and could have had compounds that affect microalgal growth. The above-mentioned nitrogen limitation could have also affected the photosynthetic activity of microalgae. Moreover, the observed low $F_{v} / F_{m}$ values in summer could be caused by photoinhibition caused by reversible damage of key PSIl components as well as higher temperatures during this season (Torzillo and Vonshak, 2013). High dissolved oxygen concentration could have partially affected the photosynthetic activity of the culture.

As highlighted before, the main goal of wastewater treatment processes based on microalgae, besides biomass production, is to recover nutrients and allow the reuse or safe disposal of large volumes of water. The $\mathrm{N}-\mathrm{NH}_{4}{ }^{+}$content in the inlet varied within 93.6 and $210.6 \mathrm{mg} \cdot \mathrm{L}^{-1}$ while the $\mathrm{N}-\mathrm{NO}_{3}{ }^{-}$content was within the range 1.9-3.7 $\mathrm{mg} \cdot \mathrm{L}^{-1}$. Considering that approximately 500-1000 $\mathrm{mg} \cdot \mathrm{m}^{-2} \cdot$ day $^{-1}$ of organic nitrogen were removed from the wastewater in both reactors, stripping led to the challenging "loss" of 550-900 and $50-150 \mathrm{mg} \cdot \mathrm{m}^{-2} \cdot \mathrm{day}^{-1}$ of $\mathrm{N}-\mathrm{NH}_{4}{ }^{+}$ in TL1 and TL2 respectively. Similar results were reported previously (Morales-Amaral et al., 2015b). Further studies to understand the effect of environmental and operational conditions

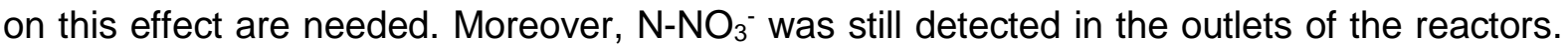
Nitrification occurred but production of $\mathrm{N}^{-\mathrm{NO}_{3}-}$ was low when compared to other processes with higher culture depths. This was caused because: (i) it was not consumed by microalgae and bacteria, because it is known that in the presence of both, $\mathrm{N}-\mathrm{NH}_{4}{ }^{+}$and $\mathrm{N}-\mathrm{NO}_{3}{ }^{-}$, microalgae 


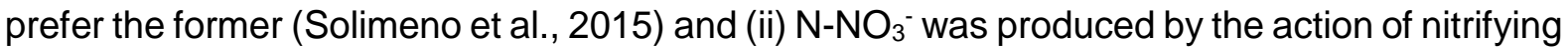
bacteria (Kwon et al., 2019). Probably the high light availability in thin-layer cascade reactor favoured microalgal growth and limited the growth of nitrifying bacteria. The composition of the microalgae-bacteria consortia is highly influenced by environmental conditions, and this could be the cause for variability in the $\mathrm{N}^{-\mathrm{NO}_{3}}{ }^{-}$removal efficiency shown in Figure 4.

Higher total nitrogen removal values were observed in TL1 when compared to TL2. This was caused by the lower surface-to-volume ratio of TL1, which allows to process a larger volume of water per surface area when compared to TL2. A different composition on the microalgaebacteria consortia of both reactors could have also affected the nutrient removal capacity of the reactors as it is not known how different surface-to-volume ratios can affect the microalgae-bacteria consortia. It is not known how photobioreactor design parameters such as channel length, culture depth, or the volume of the collector affect the composition of the microalgae-bacteria consortia. The most abundant bacterial phyla present in cultures of Scenedesmus sp. in wastewater were Proteobacteria and Bacterioidetes, with the most dominant orders being Rhodobacterales and Sphingomonadales (Sánchez Zurano et al., 2020). Moreover, a recent study suggested that the dilution rate as well as environmental conditions play a key role in the composition of the consortia, with heterotrophs and phototrophs mainly from the family Rhodobacteraceae dominating Scenedesmus sp. cultures (Collao et al., 2021). Further studies on this topic are needed as the microbial community present during microalgae cultivation highly influences the performance of the system in terms of both, biomass production and nutrient recoveries (Lian et al., 2018). Not only nitrogen but also phosphorus is a nutrient of concern in eutrophication, being both limiting factors in most growth scenarios (Anderson et al., 2002). Phosphorus and phosphorylation play a key role in the metabolism of both microalgae and bacteria (Liu et al., 2017) and previous studies demonstrated that microalgal cultures, especially when produced in thin-layer reactors, can consume large quantities of phosphorus (Morales-Amaral et al., 2015b). A mass balance revealed that the phosphorus introduced into the system was either used for microalgal growth 
or removed with the reactors outlet. This demonstrates the importance of an effective control of the $\mathrm{pH}$ as high $\mathrm{pH}$ values result in the precipitation of phosphates and therefore to a reduction of the amount of $\mathrm{P}-\mathrm{PO}_{4}{ }^{3-}$ that is available for microalgal growth. As it happened with the total nitrogen, part of the phosphorus used for microalgal growth was obtained from organic matter or from other inorganic phosphorus compounds not analysed in the current study. Further studies will include the in-depth analysis of the organic and inorganic compounds present in the inlets and outlets of the reactors as this information will be useful to design more efficient processes and maximise nutrient recoveries.

Overall, the reclaimed water could be reused for agricultural irrigation or even disposed into water courses. The content of $\mathrm{N}_{-} \mathrm{NH}_{4}{ }^{+}$and $\mathrm{N}^{-\mathrm{NO}_{3}}{ }^{-}$in the outlets was below the maximum discharge limit of Spanish regulations set at $10-15$ of $\mathrm{mg} \cdot \mathrm{L}^{-1}$ of nitrogen (BOE, 1996), and therefore based on their nitrogen content could be disposed even into sensitive zones. However, the $\mathrm{P}_{-} \mathrm{PO}_{4}{ }^{3-}$ concentration of the reactors was slightly higher than the maximum discharge limit, set at 1-2 $\mathrm{mg} \cdot \mathrm{L}^{-1}$, which would allow to dispose the effluents either into nonsensitive zones or into sensitive zones if the removal of phosphorus and nitrogen (in all the treatment plants of the sensitive zone) is larger than $75 \%$, as reported herein (BOE, 1996). One of the main advantages of microalgal processes when compared to conventional wastewater treatments is that the produced biomass can be further exploited as a source of high-value products such as animal feed or products for agriculture (biostimulants or biofertilisers). Indeed, Scenedesmus strains have potential for being used at commercial scale as biostimulants (Puglisi et al., 2020, 2018) and aquafeed ingredients (Camacho-Rodríguez et al., 2018; Vizcaíno et al., 2014). The economic analysis conducted herein suggested that producing Scenedesmus sp. using wastewater instead of freshwater and fertilisers could lead to a reduction of reduction in the unitary production cost of $0.44 € \cdot \mathrm{kg}^{-1}$ of produced wet biomass. If used for producing agricultural products, a dehydration step is not required therefore minimising production costs. The produced biomass would consist of microalgae and bacteria. As mentioned before, the composition of the consortia depends on 
environmental and operational conditions but, if managed properly, over $95 \%$ of the produced biomass will be microalgae (Herrera et al., 2020). Because of the higher light availability of thin-layer cascade reactors it is likely that photoautotrophic growth would be favoured therefore facilitating the proliferation of photosynthetic microorganisms, although this would need to be validated in future studies. An in depth characterisation of the biomass of Scenedesmus sp. produced using different types of water and photobioreactor designs is ongoing as well as a complete economic analysis comparing different reactor designs and types of water.

\section{Conclusions}

Scenedesmus sp. is a robust strain that can be produced outdoors using wastewater and thinlayer cascade reactors. Thin-layer cascade reactors are highly productive and allow to maximise biomass productivity per surface area. Biomass productivities were comparable to those obtained when produced using freshwater and commercial fertilisers as nutrients, demonstrating that primary wastewater is an excellent source of nutrient for microalgal production. However, because of the high productivity of thin-layer reactors, microalgal growth can be nutrient limited when using wastewater. The use of membranes to separate the cellular from the hydraulic retention time would allow to process a larger amount of water per surface area and increase both, the biomass productivity and the nutrient removal capacity of the system. The processed water can be reused for irrigation or even disposed into natural water courses. An advantage of microalgae based wastewater treatment processes is that besides recovering nutrients from waste, the process simultaneously produce valuable microalgal biomass that can be further used for valuable applications. A preliminary economic analysis revealed that producing microalgae using wastewater could lead to a reduction in total unitary production costs of $0.44 € \cdot \mathrm{kg}^{-1}$, which is significant when producing agricultural products.

\section{Acknowledgements}


Authors thank the Institute for Agricultural and Fisheries Research and Training (IFAPA). This work is part of the AL4BIO Project, funded by the Spanish Ministry of Science, Innovation and Universities (RTI2018-099495) and the SABANA Project funded by the H2020 Research and Innovation Framework Programme (727874). Tomás Lafarga thanks the Spanish Ministry of Science, Innovation and Universities (IJC2018-035287-I).

\section{Declaration of competing interest}

The authors declare that they have no competing financial interests or personal relationships that could have appeared to influence the work reported in this paper.

\section{Data availability}

Data from the SABANA Project are available at http://www2.ual.es/sabana/data-center-2/.

\section{CRediT author statement}

Ainoa Morillas-España: Investigation, Writing - original draft; Tomás Lafarga: Formal analysis, Visualization, Writing - review \& editing; Francisco Gabriel Acién-Fernández: Supervision, Funding acquisition; Cintia Gómez-Serrano: Investigation, Formal analysis; Cynthia Victoria González-López: Supervision, Funding acquisition. 
Figure legends

Figure 1. Annual variation of (A) solar radiation and (B) temperature inside the greenhouse and (C) photobioreactors used. Values represent the average of the maximum, minimum, and average daily radiation and temperature values inside the greenhouse \pm SD. In the case of solar radiation, only sunlight hours were considered for calculating the average. The environmental data of our facilities are available at http://www2.ual.es/sabana/data-center-2/

Figure 2. Effect of environmental conditions on culture temperature, dissolved oxygen concentration, and $\mathrm{pH}$ in (A) TL1 and (B) TL2. Values represent the average of the daily maximum, minimum, and average values \pm SD. Temperature, dissolved oxygen concentration, and $\mathrm{pH}$ data of our reactors are available at http://www2.ual.es/sabana/data-center-2/

Figure 3. (A) Biomass productivity and (B) chlorophyll fluorescence

Figure 4. (A) $\mathrm{N}_{-} \mathrm{NH}_{4}{ }^{+}$, (B) $\mathrm{N}-\mathrm{NO}_{3}{ }^{-}$, (C) total nitrogen, and (D) $\mathrm{P}-\mathrm{PO}_{4}{ }^{3-}$ removal capacity of the system 
Figure 1

(A)

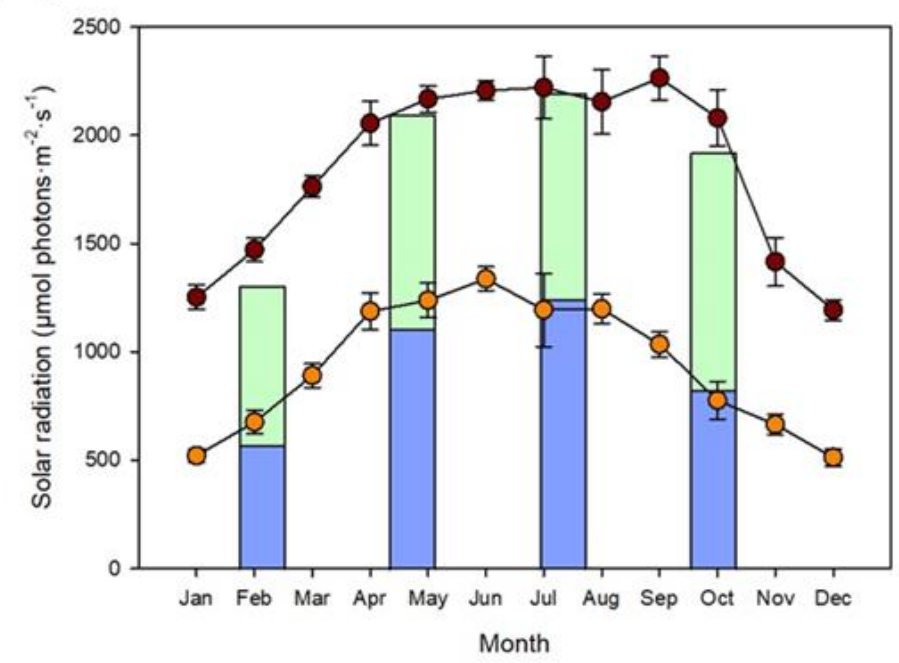

- Daily maximum (month) Daily maximum (season) - - Average $-12 \mathrm{~h}$ of sunlight (month) $\square$ Average $-12 \mathrm{~h}$ of sunlight (season)

(C)

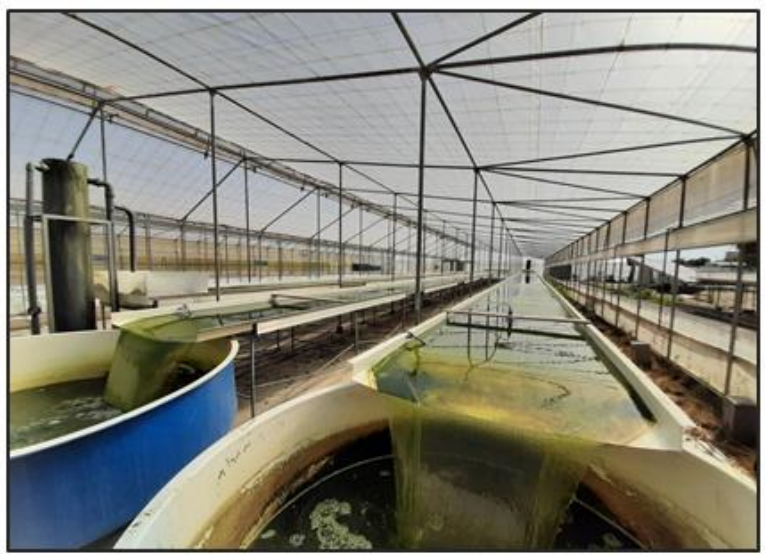

TL1: One-cannel thin-layer reactor

Channel length: $52.5 \mathrm{~m}$

Channel width: $1.2 \mathrm{~m}$

Area: $63 \mathrm{~m}^{2}$

Culture depth: $0,02 \mathrm{~m}$

Operating volume: $2.4 \mathrm{~m}^{3}$

Slope: $1 \%$

Volume in the collector: $1.1 \mathrm{~m}^{3}$

Degasser: $250 \mathrm{~L}$ bubble column

Air flow: $75 \mathrm{~L} \cdot \mathrm{min}^{-1}$
(B)

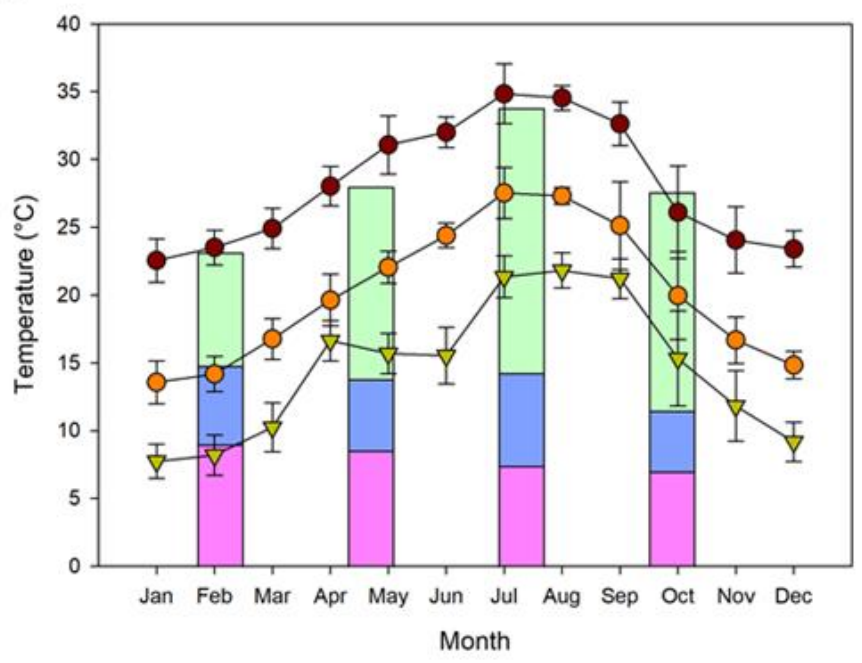

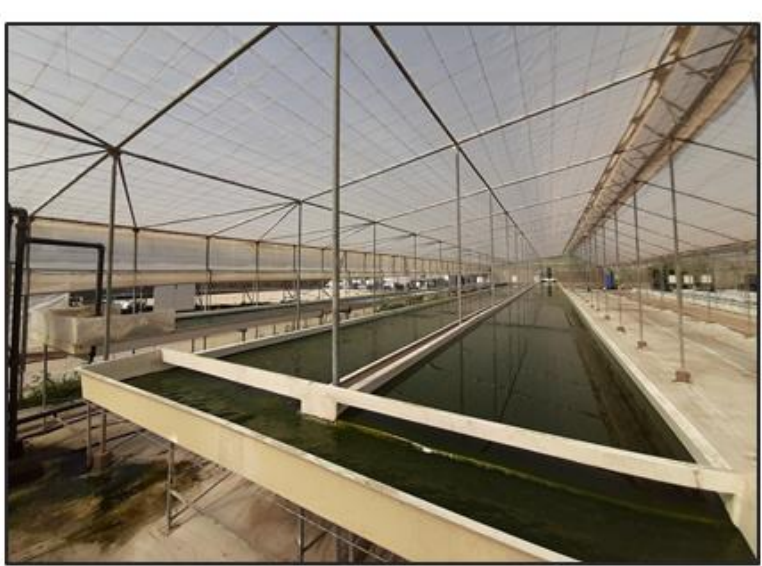

TL2: Two-cannel thin-layer reactor

Channel length: $105 \mathrm{~m}$

Channel width: $1.2 \mathrm{~m}$

Area: $126 \mathrm{~m}^{2}$

Culture depth: $0,02 \mathrm{~m}$

Operating volume: $3.6 \mathrm{~m}^{3}$

Slope: $1 \%$

Volume of the collector: $1.1 \mathrm{~m}^{3}$

Degasser: $250 \mathrm{~L}$ bubble column

Air flow: $75 \mathrm{~L} \cdot \mathrm{min}^{-1}$ 
Figure 2

(A)

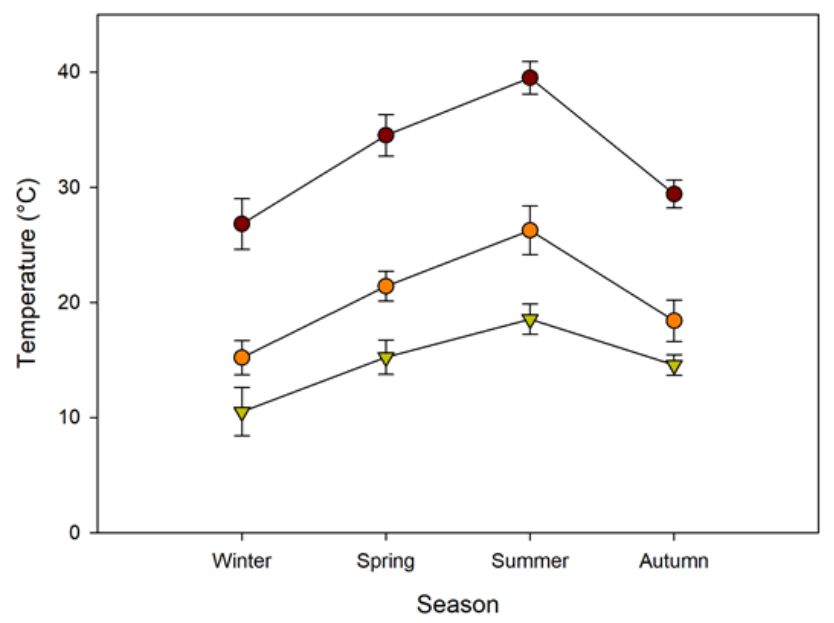

-o- Maximum

- - Average

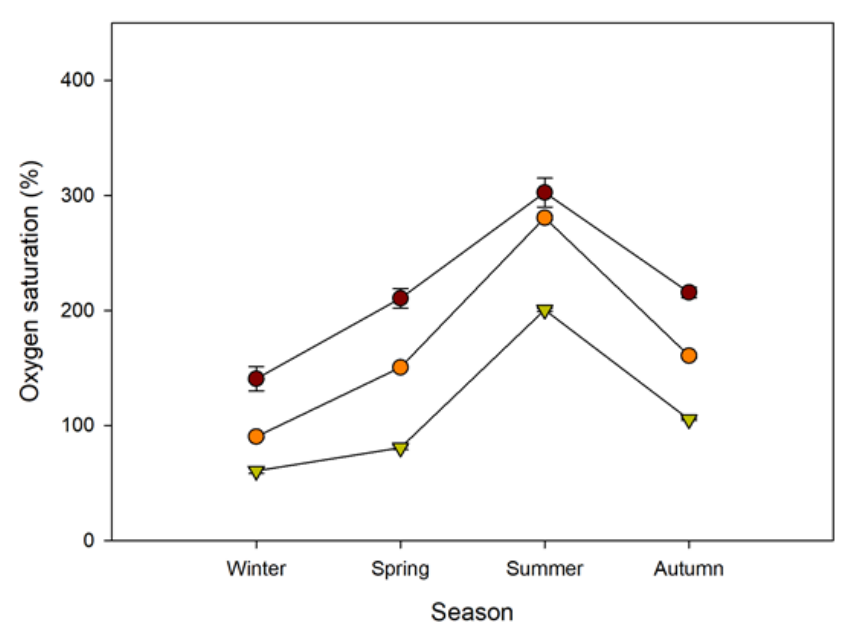

-0-Maximum

-0 - Average
$\rightarrow-$ Minimum

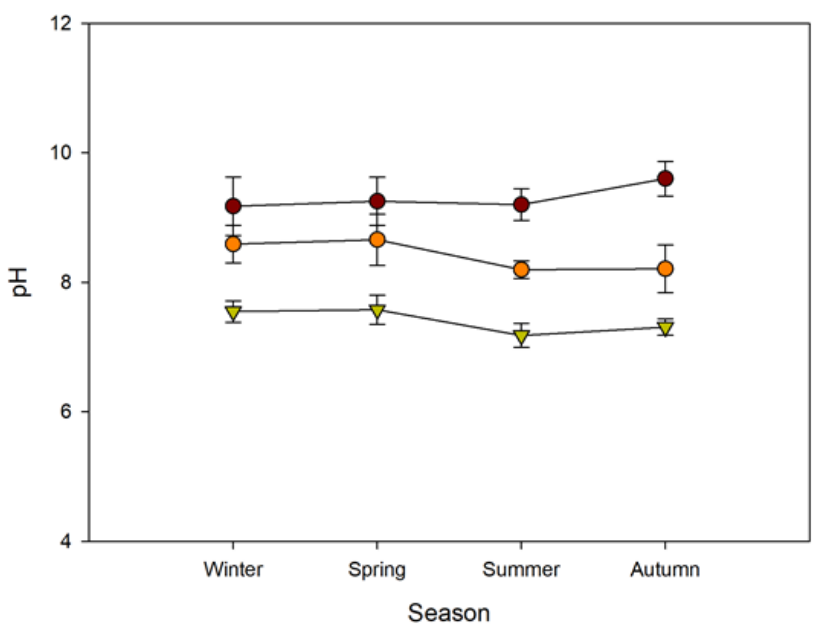

(B)
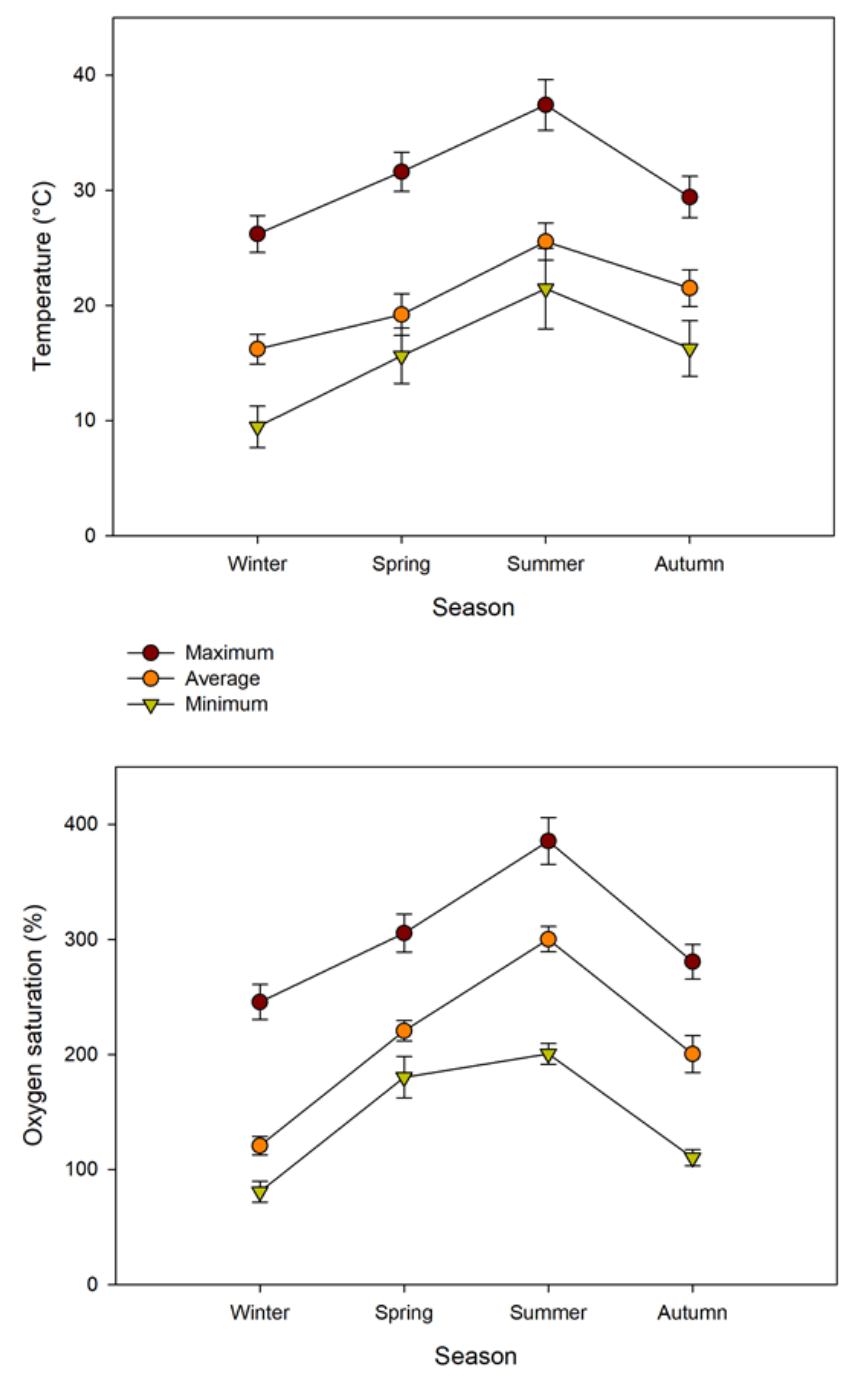

-- Maximum

-0 - Average
$\rightarrow-$ Minimum

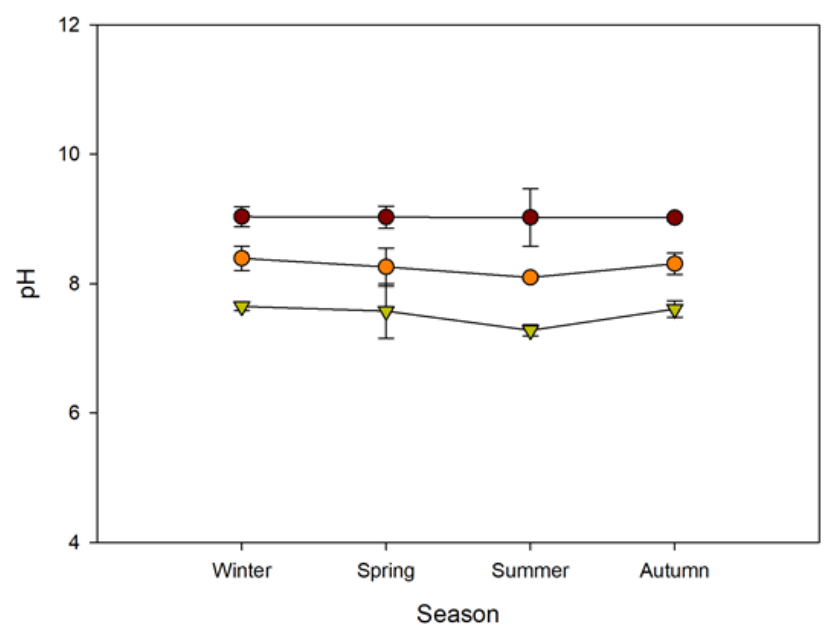

-0- Maximum

- - Average
$-\nabla-$ Minimum 
Figure 3

(A)

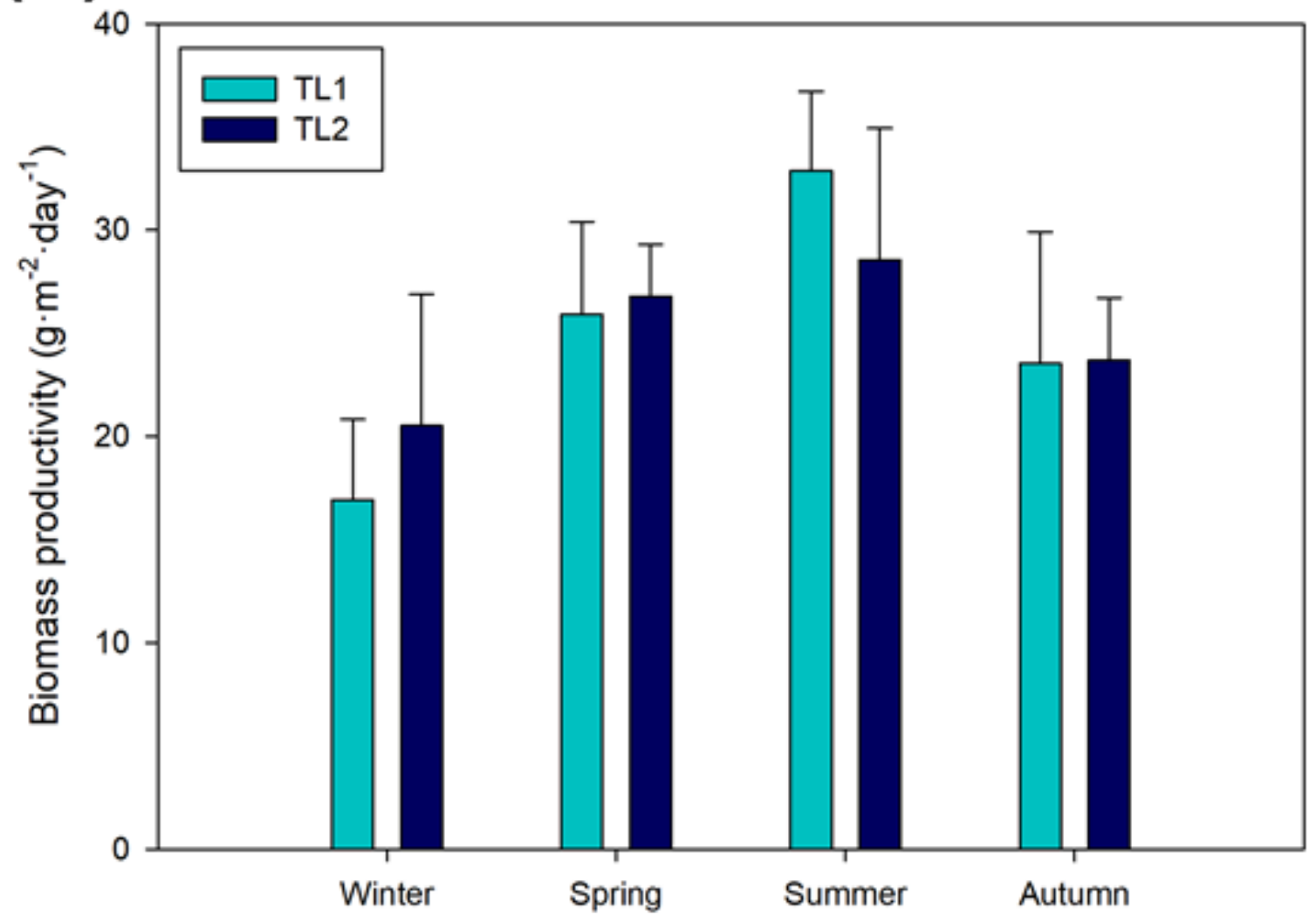

(B)

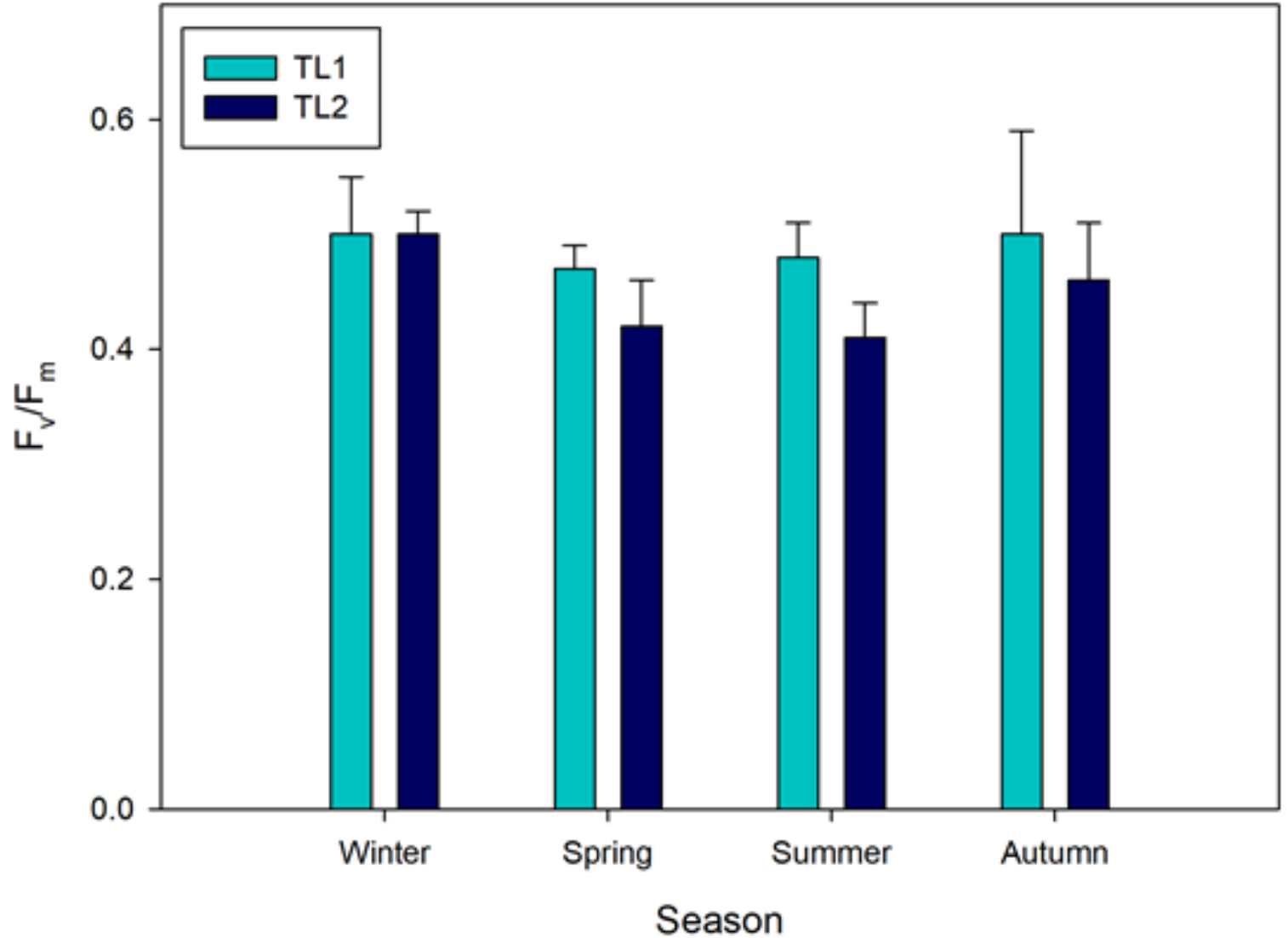


Figure 4

(A)

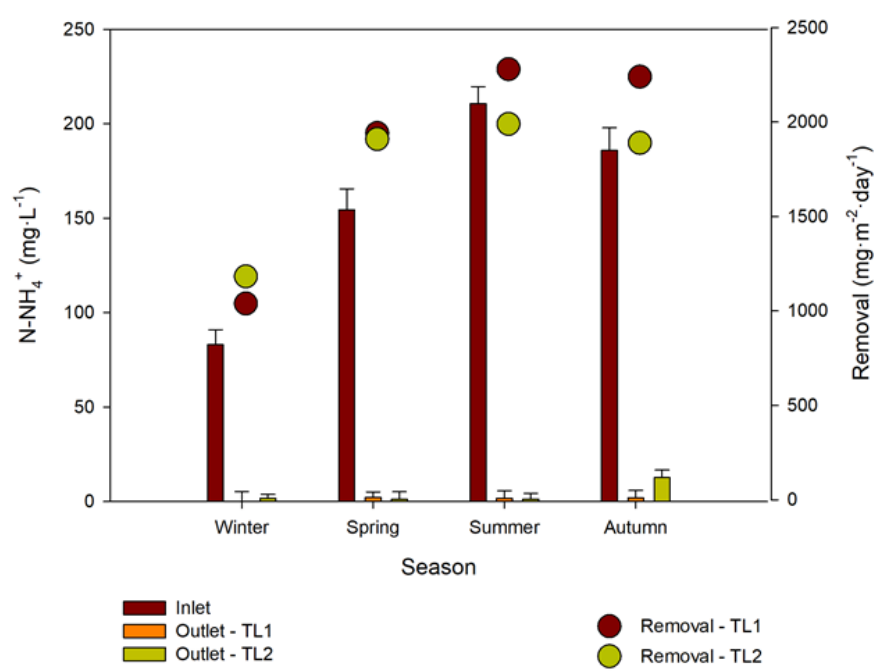

(C)

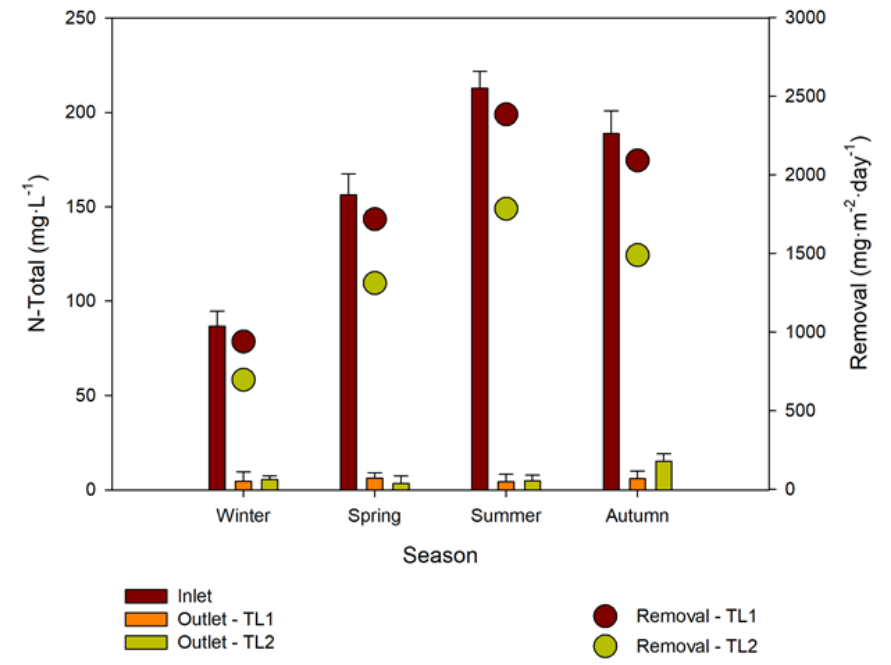

(B)

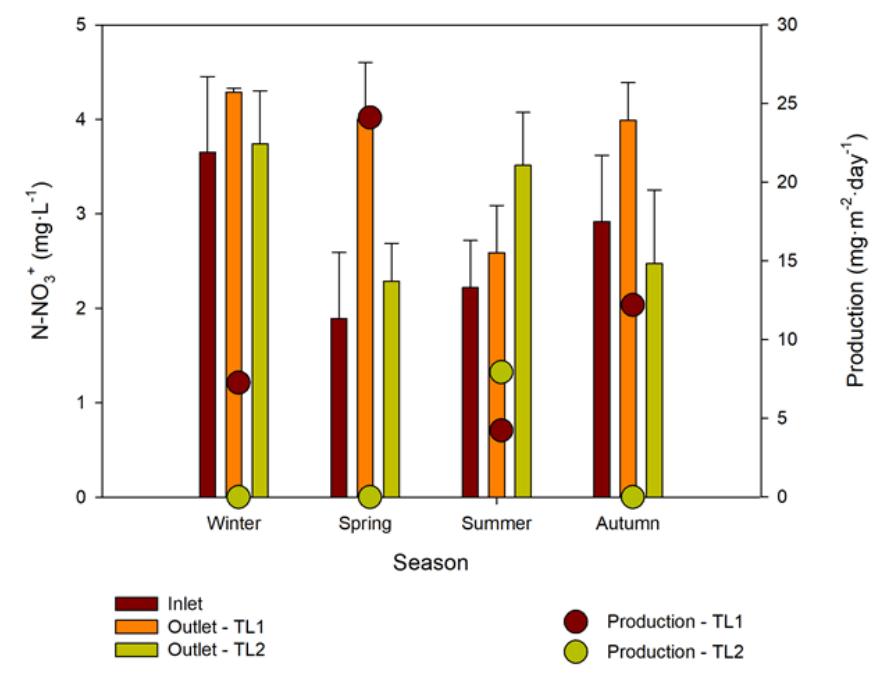

(D)

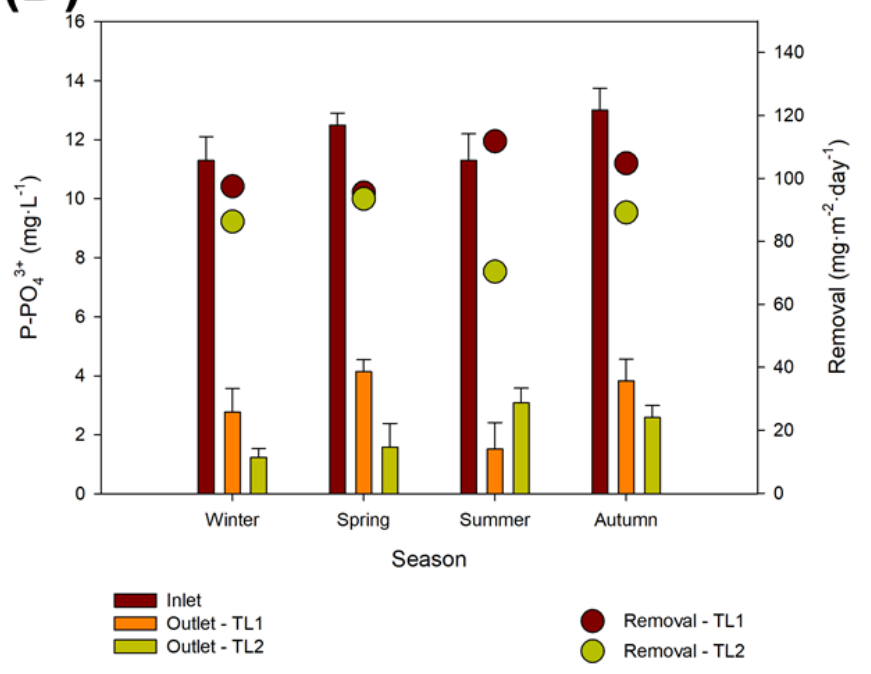




\section{References}

Acién, F.G., Fernández, J.M., Magán, J.J., Molina, E., 2012. Production cost of a real microalgae production plant and strategies to reduce it. Biotechnol. Adv. 30, 13441353. https://doi.org/10.1016/j.biotechadv.2012.02.005

Anderson, D.M., Glibert, P.M., Burkholder, J.M., 2002. Harmful algal blooms and eutrophication: Nutrient sources, composition, and consequences. Estuaries 25, 704726. https://doi.org/10.1007/BF02804901

Barceló-Villalobos, M., Fernández-del Olmo, P., Guzmán, J.L.L., Fernández-Sevilla, J.M.M., Acién Fernández, F.G., Olmo, P.F., Guzmán, J.L.L., Fernández-Sevilla, J.M.M., Fernández, F.G.A., 2019a. Evaluation of photosynthetic light integration by microalgae in a pilot-scale raceway reactor. Bioresour. Technol. 280, 404-411. https://doi.org/10.1016/j.biortech.2019.02.032

Barceló-Villalobos, M., Serrano, C.G., Zurano, A.S., García, L.A., Maldonado, S.E., Peña, J., Fernández, F.G.A., 2019b. Variations of culture parameters in a pilot-scale thin-layer reactor and their influence on the performance of Scenedesmus almeriensis culture. Bioresour. Technol. Reports. https://doi.org/10.1016/j.biteb.2019.03.007

BOE, 1996. Real Decreto 509/1996, de 15 de marzo, de desarrollo del Real Decreto-ley 11/1995, de 28 de diciembre, por el que se establecen las normas aplicables al tratamiento de las aguas residuales urbanas. Bol. Of. del Estado 77, 12038-12041.

Camacho-Rodríguez, J., Macías-Sánchez, M.D., Cerón-García, M.C., Alarcón, F.J., MolinaGrima, E., 2018. Microalgae as a potential ingredient for partial fish meal replacement in aquafeeds: nutrient stability under different storage conditions. J. Appl. Phycol. https://doi.org/10.1007/s10811-017-1281-5

Collao, J., Morales-Amaral, M. del M., Acién-Fernández, F.G., Bolado-Rodríguez, S., Fernandez-Gonzalez, N., 2021. Effect of operational parameters, environmental 
conditions, and biotic interactions on bacterial communities present in urban wastewater treatment photobioreactors. Chemosphere 284, 131271. https://doi.org/10.1016/j.chemosphere.2021.131271

Doucha, J., Lívanský, K., 2009. Outdoor open thin-layer microalgal photobioreactor: Potential productivity. J. Appl. Phycol. https://doi.org/10.1007/s10811-008-9336-2

Herrera, A., D’Imporzano, G., Acién Fernandez, F.G., Adani, F., 2020. Sustainable production of microalgae in raceways: Nutrients and water management as key factors influencing environmental impacts. J. Clean. Prod.

https://doi.org/10.1016/j.jclepro.2020.125005

Kwon, G., Kim, H., Song, C., Jahng, D., 2019. Co-culture of microalgae and enriched nitrifying bacteria for energy-efficient nitrification. Biochem. Eng. J. https://doi.org/10.1016/j.bej.2019.107385

Lafarga, T., 2020. Cultured Microalgae and Compounds Derived Thereof for Food Applications: Strain Selection and Cultivation, Drying, and Processing Strategies. Food Rev. Int. 36. https://doi.org/10.1080/87559129.2019.1655572

Lian, J., Wijffels, R.H., Smidt, H., Sipkema, D., 2018. The effect of the algal microbiome on industrial production of microalgae. Microb. Biotechnol. 11, 806-818. https://doi.org/10.1111/1751-7915.13296

Liu, J., Wu, Y., Wu, C., Muylaert, K., Vyverman, W., Yu, H.Q., Muñoz, R., Rittmann, B., 2017. Advanced nutrient removal from surface water by a consortium of attached microalgae and bacteria: A review. Bioresour. Technol. https://doi.org/10.1016/j.biortech.2017.06.054

Morales-Amaral, M. del M., Gómez-Serrano, C., Acién, F.G., Fernández-Sevilla, J.M., Molina-Grima, E., 2015a. Production of microalgae using centrate from anaerobic digestion as the nutrient source. Algal Res. 9, 297-305. 
https://doi.org/10.1016/j.algal.2015.03.018

Morales-Amaral, M. del M., Gómez-Serrano, C., Acién, F.G., Fernández-Sevilla, J.M., Molina-Grima, E., 2015b. Outdoor production of Scenedesmus sp. in thin-layer and raceway reactors using centrate from anaerobic digestion as the sole nutrient source. Algal Res. 12, 99-108. https://doi.org/10.1016/j.algal.2015.08.020

Morillas-España, A., Lafarga, T., Gómez-Serrano, C., Acién-Fernández, F.G., GonzálezLópez, C.V., 2020. Year-long production of Scenedesmus almeriensis in pilot-scale raceway and thin-layer cascade photobioreactors. Algal Res. 51, 102069. https://doi.org/10.1016/j.algal.2020.102069

Muga, H.E., Mihelcic, J.R., 2008. Sustainability of wastewater treatment technologies. J. Environ. Manage. 88, 437-447. https://doi.org/10.1016/j.jenvman.2007.03.008

Puglisi, I., Barone, V., Sidella, S., Coppa, M., Broccanello, C., Gennari, M., Baglieri, A., 2018. Biostimulant activity of humic-like substances from agro-industrial waste on Chlorella vulgaris and Scenedesmus quadricauda. Eur. J. Phycol. 53, 433-442. https://doi.org/10.1080/09670262.2018.1458997

Puglisi, I., La Bella, E., Rovetto, E.I., Lo Piero, A.R., Baglieri, A., 2020. Biostimulant Effect and Biochemical Response in Lettuce Seedlings Treated with A Scenedesmus quadricauda Extract. Plants 9, 123. https://doi.org/10.3390/plants9010123

Raeisossadati, M., Vadiveloo, A., Bahri, P.A., Parlevliet, D., Moheimani, N.R., 2019. Treating anaerobically digested piggery effluent (ADPE) using microalgae in thin layer reactor and raceway pond. J. Appl. Phycol. 31, 2311-2319. https://doi.org/10.1007/s10811019-01760-6

Sánchez-Zurano, A., Ciardi, M., Lafarga, T., Fernández-Sevilla, J.M., Bermejo, R., MolinaGrima, E., 2021. Role of Microalgae in the Recovery of Nutrients from Pig Manure. Processes 9, 203. https://doi.org/10.3390/pr9020203 
Sánchez, J.F., Fernández, J.M., Acién, F.G., Rueda, A., Pérez-Parra, J., Molina, E., 2008. Influence of culture conditions on the productivity and lutein content of the new strain Scenedesmus almeriensis. Process Biochem. https://doi.org/10.1016/j.procbio.2008.01.004

Sánchez, J.F.F., Fernández-Sevilla, J.M.M., Acién, F.G.G., Cerón, M.C.C., Pérez-Parra, J., Molina-Grima, E., 2008. Biomass and lutein productivity of Scenedesmus almeriensis: Influence of irradiance, dilution rate and temperature. Appl. Microbiol. Biotechnol. 79, 719-729. https://doi.org/10.1007/s00253-008-1494-2

Sánchez Zurano, A., Garrido Cárdenas, J.A., Gómez Serrano, C., Morales Amaral, M., Acién-Fernández, F.G., Fernández Sevilla, J.M., Molina Grima, E., 2020. Year-long assessment of a pilot-scale thin-layer reactor for microalgae wastewater treatment. Variation in the microalgae-bacteria consortium and the impact of environmental conditions. Algal Res. 50, 101983. https://doi.org/10.1016/j.algal.2020.101983

Santabarbara, S., Villafiorita Monteleone, F., Remelli, W., Rizzo, F., Menin, B., Casazza, A.P., 2019. Comparative excitation-emission dependence of the $F_{V} / F_{M}$ ratio in model green algae and cyanobacterial strains. Physiol. Plant. 166, 351-364. https://doi.org/10.1111/ppl.12931

Sgroi, M., Vagliasindi, F.G.A., Roccaro, P., 2018. Feasibility, sustainability and circular economy concepts in water reuse. Curr. Opin. Environ. Sci. Heal. https://doi.org/10.1016/j.coesh.2018.01.004

Smol, M., Adam, C., Preisner, M., 2020. Circular economy model framework in the European water and wastewater sector. J. Mater. Cycles Waste Manag. https://doi.org/10.1007/s10163-019-00960-z

Solimeno, A., Samsó, R., Uggetti, E., Sialve, B., Steyer, J.-P., Gabarró, A., García, J., 2015. New mechanistic model to simulate microalgae growth. Algal Res. 12, 350-358. https://doi.org/10.1016/j.algal.2015.09.008 
Torzillo, G., Vonshak, A., 2013. Environmental Stress Physiology with Reference to Mass Cultures. John Wiley and Sons, pp. 90-113.

https://doi.org/10.1002/9781118567166.ch6

Vizcaíno, A.J., López, G., Sáez, M.I., Jiménez, J.A., Barros, A., Hidalgo, L., CamachoRodríguez, J., Martínez, T.F., Cerón-García, M.C., Alarcón, F.J., 2014. Effects of the microalga Scenedesmus almeriensis as fishmeal alternative in diets for gilthead sea bream, Sparus aurata, juveniles. Aquaculture.

https://doi.org/10.1016/j.aquaculture.2014.05.010

Wang, J., Zhou, W., Chen, H., Zhan, J., He, C., Wang, Q., 2019. Ammonium nitrogen tolerant Chlorella strain screening and its damaging effects on photosynthesis. Front. Microbiol. 10, 3250. https://doi.org/10.3389/fmicb.2018.03250

Wang, R., Tian, Y., Xue, S., Zhang, D., Zhang, Q., Wu, X., Kong, D., Cong, W., 2016. Enhanced microalgal biomass and lipid production via co-culture of Scenedesmus obliquus and Candida tropicalis in an autotrophic system. J. Chem. Technol. Biotechnol. 91, 1387-1396. https://doi.org/10.1002/jctb.4735 